\title{
Field investigations of pumping activity of the facultatively filter-feeding polychaete Nereis diversicolor using an improved infrared phototransducer system
}

\author{
Anders Vedel, Bent Bach Andersen, Hans Ulrik Riisgård \\ Institute of Biology, Odense University, Campusvej 55, DK-5230 Odense M, Denmark
}

\begin{abstract}
Field data were obtained that document the extent to which the facultatively filter-feeding polychacte Nereis diversicolor undertakes suspension feeding at different times of the year in 2 Danish shallow water areas, eutrophicated (Odense Fjord) and unpolluted (Fyns Hoved). A modified phototransducer system was used to make continuous long-term recordings of the characteristic undulating body movements (pumping activity) indicative of filter feeding. Filter feeding was 'triggered' by the presence of phytoplankton in the water, and the worm was filter feeding 50 to $100 \%$ of the time monitored during the productive summer period. In early spring and autumn filter feeding occurred for about 5 to $20 \%$ of total time. At Fyns Hoved in September, when light was beginning to be a limiting factor for primary production, the chlorophyll a (chl a) concentration fluctuated around the trigger

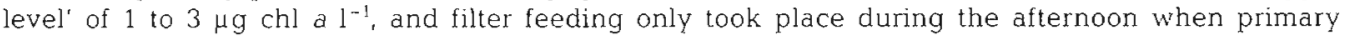
production had elevated the phytoplankton biomass above the trigger level. The grazing impact of $N$. diversicolor (potentially $5.6 \mathrm{~m}^{3} \mathrm{~m}^{-2} \mathrm{~d}^{-1}$ in May, representing a volume 11 to 55 times greater than the overlying water column in Odense Fjord) was probably restricted on days with low wind-caused mixing of the water column by a thin layer of refiltered water overlying the sediment. lncreased pumping activity with rising temperature led to a doubling of the population filtration potential from March to June in Odense Fjord even though the population biomass was concomitantly reduced by $30 \%$. No temperature adaptation of pumping activity was found in $N$. diversicolor. This study confirms that $N$. diversicolor utilizes a number of feeding methods, depending on season, phytoplankton biomass and local conditions.
\end{abstract}

KEY WORDS: Filtration activity · Grazing impact · Field monitoring

\section{INTRODUCTION}

The facultatively filter-feeding polychaete Nereis diversicolor lives in U-shaped tubes in soft bottom sediments in shallow brackish-water areas in northwestern Europe. It has recently been suggested that the grazing impact of $N$. diversicolor, with population filtration rates being of the order of $10 \mathrm{~m}^{3} \mathrm{~m}^{-2} \mathrm{~d}^{-1}$, has to date been grossly underestimated (Riisgård 1991b). It was pointed out by Riisgård et al. (1992) that it is of great ecological importance to determine the extent to which $N$, diversicolor actually uses its ability to filter the water column in assessing the potential of this species to limit phytoplankton production.
In this study we present for the first time field data that document the extent to which $N$. diversicolor undertakes suspension feeding at different times of the year in 2 shallow water areas (eutrophic versus unpolluted).

\section{MATERIALS AND METHODS}

All experiments were performed with the ragworm Nereis diversicolor O. F. Müller of 47 to $63 \mathrm{mg}$ body dry weight transferred to U-shaped glass tubes $(22 \mathrm{~cm}$ length, $4.0 \mathrm{~mm}$ internal diameter). A modified infrared phototransducer system developed by Depledge \& 
Andersen (1990) was used to monitor the filter-feeding activity of worms in glass tubes immersed in the natural sediment (Fig. 1), in 2 areas, Odense Fjord (mean water depth $0.8 \mathrm{~m}$, mean salinity $10 \%$ ) and Pughavn $(0.5 \mathrm{~m}, 22 \% \mathrm{~S})$ at Fyns Hoved, northern Fyn, Denmark (Fig. 2). The tidal amplitude at both locations is ca $30 \mathrm{~cm}$. Both locations are characterized by dense populations of $N$. diversicolor: about 3000 ind. $\mathrm{m}^{-2}$ in Odense Fjord and 2000 ind. $\mathrm{m}^{-2}$ in Pughavn.

Filter-feeding monitoring. The phototransducer system used by Riisgård (1991b) and Riisgård et al. (1992) allowed continuous long-term measurements of the characteristic undulating body movements, measured as stroke frequency, when the worm is suspension feeding. When feeding, the worm vigorously pumps water through the tube with the filter net for periods of typically 5 to $15 \mathrm{~min}$ before the net with retained particles is swallowed and a new pumping cycle started. An improved version of this phototransducer system, originally developed by Depledge \& Andersen (1990) for long-term recording of cardiac activity in invertebrates, was adapted for the field investigations of filter-feeding activity of Nereis diversicolor described here.

The phototransducer system consists of an infrared (i.r.) light-emitting diode and a phototransistor detector. Both elements are mounted parallel to each other, facing the same direction. Because the worm can move freely within the glass tube and commence net spinning at either end of the tube, 2 transducers were required (Fig, 1). The phototransistor detects variations in reflected i.r. light intensity, which is a function of the undulating body activity of the filter-feeding worm, and the reflected i.r. light generates a light-dependent current. This current is amplified and filtered prior to input to an $\mathrm{A} / \mathrm{D}$ converter connected to a portable personal computer (Sharp PC 4600). Real-time signals from the transducers were displayed on the computer screen in 4 oscilloscope-like windows. Threshold levels (Fig. 1D), and undulatory strokes per minute ('counts') were presented in histogram windows (Fig. 1E). Noise in the signal ('knees', Fig. 1D) could sometimes overshoot the upper threshold (UT), which was then adjusted by means of a software window discriminator. An undulatory worm movement was only counted when the signal had passed through both the UT and the lower threshold (LT). The software programme selected the channel with the highest count per sweep (300 points) as increment of its total count, and the total activity from the transducers ( 2 per worm. Fig. 1B) was gathered in 1 histogram per worm. This procedure enabled counting of undulatory movements when the worm occasionally activated both transducers. All histogram data were stored on disk (ASCII

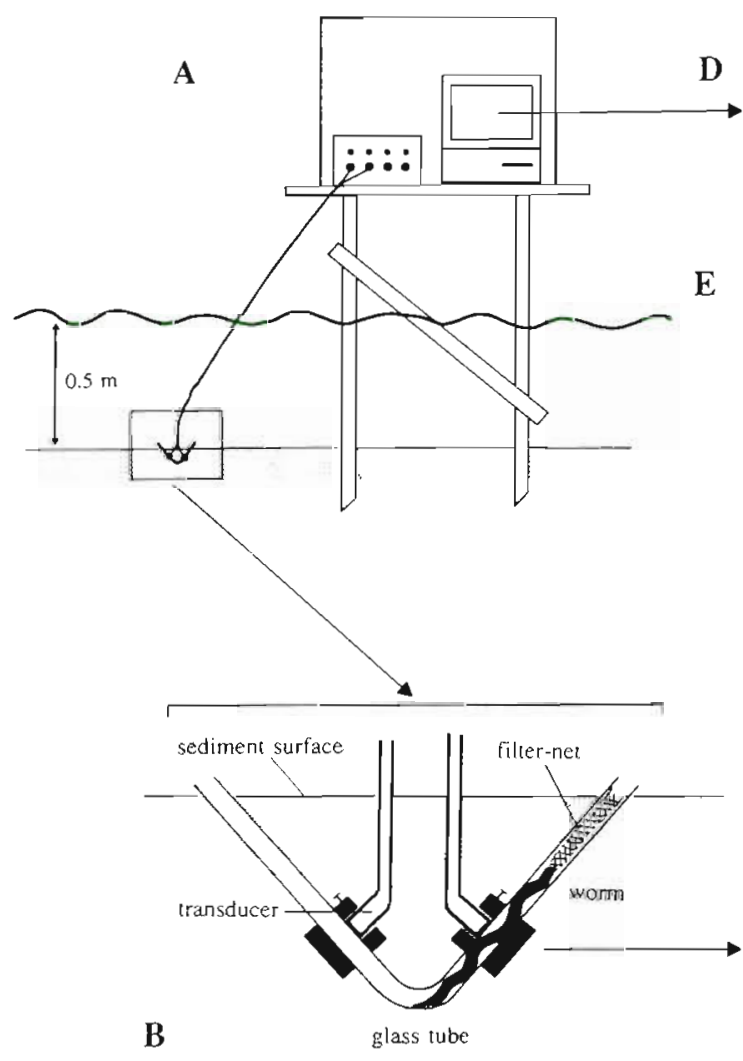

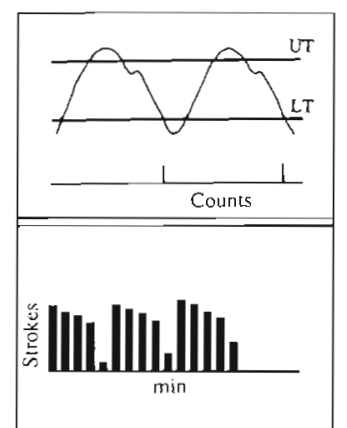

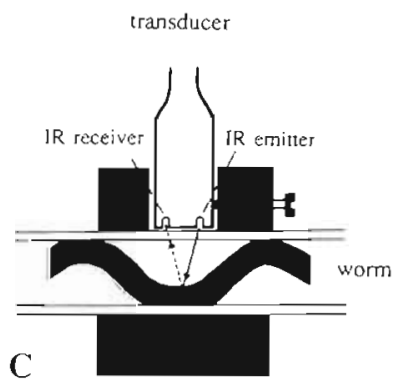

Fig. 1. Nereis diversicolor. Schematic presentation of the U-shaped glass tubes in which worms were placed and the phototransducer system for monitoring filter-feeding activity in the field studies. (A) Platform with computer and phototransducer system connected to a glass tube holding a worm. (B) The phototransducer detects variations affected by the movements of the worm (C) and the signals are shown in the oscilloscopelike window on the computer screen (D). Only signals which that have passed the upper (UT) and lower (LT) thresholds are counted and included in the column chart (E) which shows the recorded undulatory body strokes per min. Periods (typically 5 to $15 \mathrm{~min}$, depending on temperature) with high stroke frequency $(30$ to 60 strokes $\mathrm{min}^{-1}$, depending on temperature) followed by a pause (feeding and net-spinning) are easily recognized as representing filterfeeding activity 


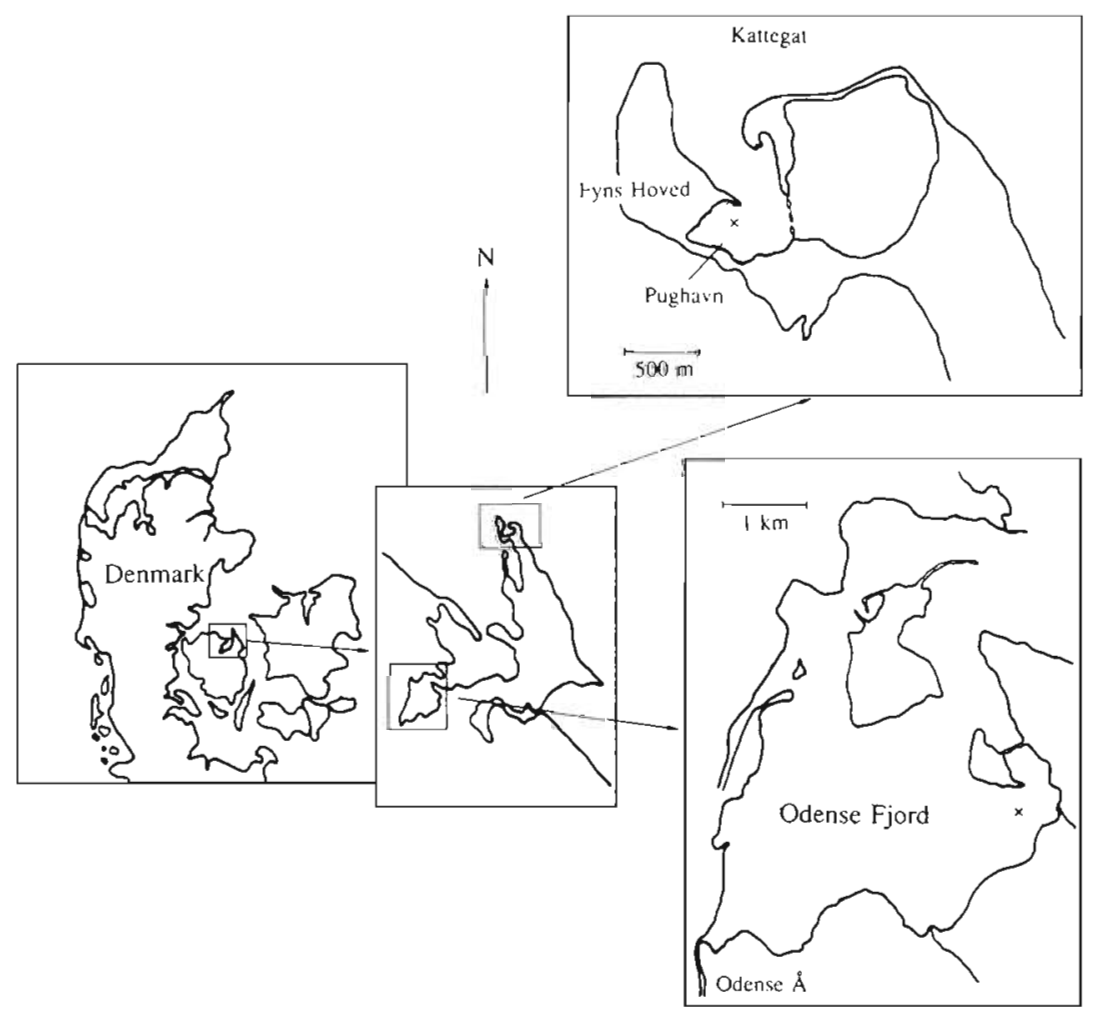

Fig. 2. Nereis diversicolor. Locations ( $\mathrm{x}$, Odense Fjord and Pughavn at Fyns Hoved) at which field monitoring of filter feeding were performed. Shaded areas indicate distribution of $N$. diversicolor; hatched area is a mussel bed

formed in the following way (Fig. 3): The Ch no. was set by $<\mathrm{D} 0\rangle$ to $\langle\mathrm{D} 2\rangle$, and latched by a strobe on $<D 3>$. A/D conversion was started by a strobe on $\langle D 4\rangle$, Data were transferred to the CA4034 by a strobe on $\langle D 7\rangle$. The output was enabled (parallel mode) by ' 1 ' on <D6>, and the 4 high bytes could be read on the input of the parallel port $<\mathrm{ER}\rangle\langle\mathrm{SE}\rangle\langle\mathrm{PE}\rangle\langle\mathrm{AC}\rangle$. To shift the 4 low bits to the 4 high bit positions, the serial mode was enabled by ' 0 ' on $\langle$ D $6>$ and sending 4 clock pulses to $\langle$ D5 $>$. Output was enabled (parallel mode) by ' 1 ' on <D6> and the 4 low bytes can be read on the input of the parallel port $\langle E R\rangle$ $\langle\mathrm{SE}\rangle\langle\mathrm{PE}\rangle\langle\mathrm{AC}\rangle$. The program shifts and recombines low and high bytes, and a new conversion can start.

Field monitoring of filter feeding. Four days prior to making field measurements of filter feeding activity, a number of worms were caught and transferred to U-shaped glass tubes which were then buried in the sediment in an upright position with the openings at the surface of the sediment as in a natural tube

format) in the format of a text file for easy import into a spreadsheet (Lotus or Quattro).

The phototransducer system described by Depledge \& Andersen (1990) was modified to enable field studies as follows.

Hardware: Frequency range: HighPass $0.7 \mathrm{~Hz}, 20 \mathrm{~dB}$ decade ${ }^{-1}$; LowPass $2.5 \mathrm{~Hz}_{4} 40 \mathrm{~dB}$ decade $^{-1}$; gain $60 \mathrm{~dB}$; 2 transducers were used per animal; an A/D converter ( 8 bit, 4 channel) was used as an interface; level discriminators were changed to window discriminators with adjustable upper and lower threshold.

$A / D$ hardware: Battery-operated personal computers normally lack the possibility to use standard interface cards. A fast 8 bit 8 channel A/D interface connected to the standard printer port (parallel) was constructed (Fig. 3). The ML2258 from Micro Linear combines an 8 bit A/D converter, 8 channel analog multiplexer and 8 bit parallel interface in a single monolithic CMOS device. The printer port has 8 output lines $(<D 0>$ to $\langle\mathrm{D} 7\rangle$; address: $\$ 3 \mathrm{BC}$ ), but only 4 input lines $(<E R\rangle$, $\langle\mathrm{SE}\rangle,\langle\mathrm{PE}\rangle,\langle\mathrm{AC}\rangle$; address: $\$ 3 \mathrm{BD}$ ). The CA4034 converts the 8 bit to 2 times 4 bit.

A/D programming: Turbo Pascal (version 5) was used as the programming language. Channel (Ch) selection, $\mathrm{A} / \mathrm{D}$ conversion and data transfer to the $\mathrm{PC}$ were per-
(Fig. 1B). Earlier field experiments have shown that about $70 \%$ of the worms willingly stay in the glass tubes for $14 \mathrm{~d}$ (Vedel \& Riisgård 1993). After the 'adaptation' period ( $4 \mathrm{~d}$ ) the monitoring system was switched on and filter feeding activity was recorded for up to $3 \mathrm{~d}$. As the phototransducer monitoring system only allows 2 worms to be monitored at the same time, a number of 'secondary' or parallel tubes with worms were monitored to complement the statistics of data recordings. This was achieved by connecting the 'secondary' worm-tubes to the computer system for periods of 5 to 10 min every second hour. Water temperature, water depth and algal biomass [expressed as chlorophyll a (chl a)] were measured at the field sites every second or third hour during the monitoring period. Water samples for chl a determination were taken near the surface by means of a plastic bottle $(0.5$ to $5 \mathrm{l})$. The phytoplankton was filtered (GF/C filter) and extracted in $96 \%$ ethanol (within 30 to $60 \mathrm{~min}$ after sampling). Absorption of extracted chl a was measured at $665 \mathrm{~nm}$ (Perkin-Elmer model 554) and the concentration estimated according to the calculation of Arvola (1981).

Laboratory test: frame of reference for field measurements. To test the phototransducer monitoring system and to obtain a frame of reference to allow the 


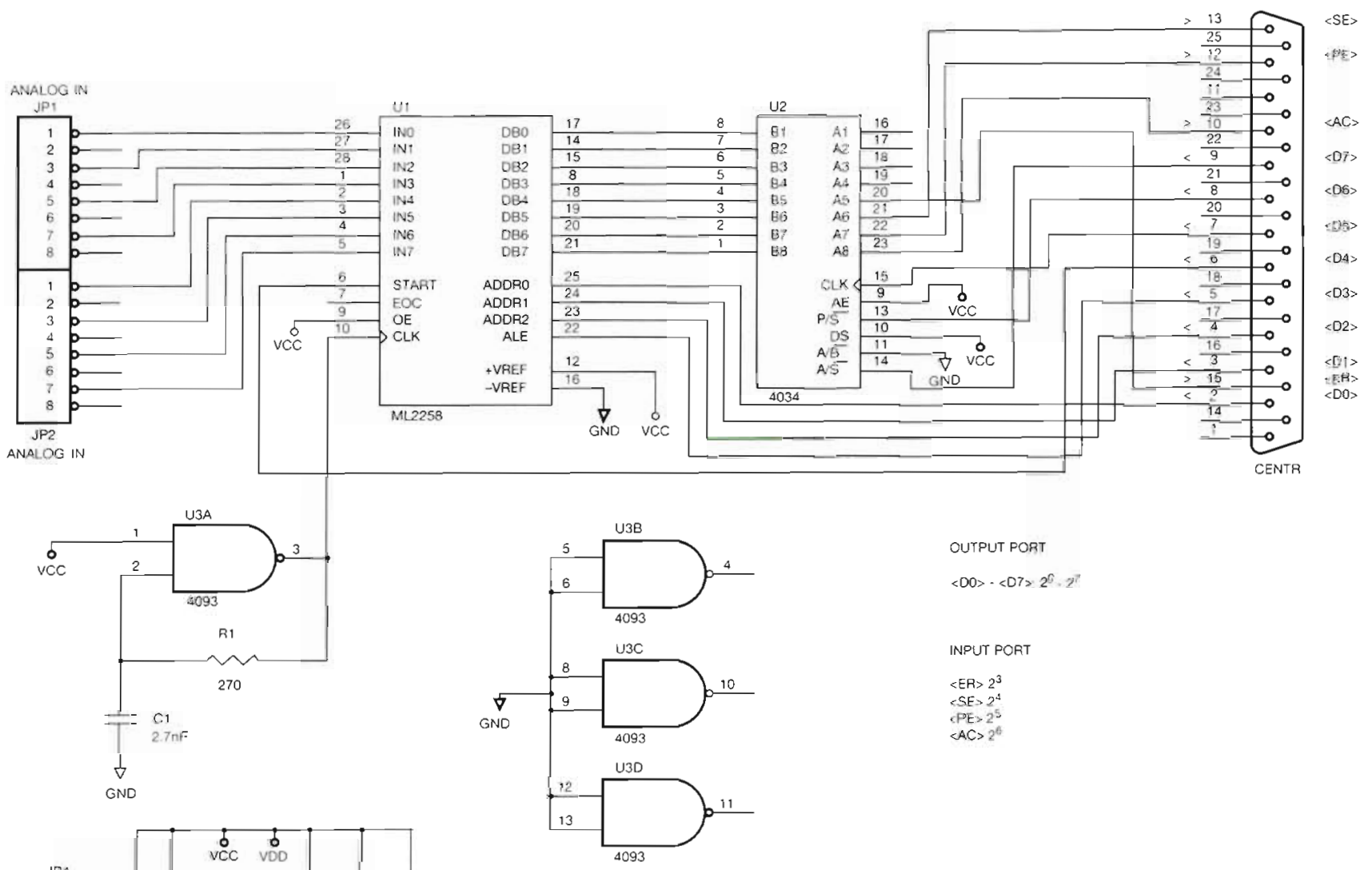

Fig. 3. A/D diagram of the phototransducer system (see also the circuit diagrams shown on Fig. 3 in Depledge \& Andersen 1990)

interpretation of field recordings, a number of laboratory experiments with different algal concentrations were performed. Fig. 4 shows a typical example. Twenty-five worms were kept in an $10 \mathrm{l}$ aquarium with natural unfiltered or biofiltered (Mytilus edulis) through-flowing seawater. One of the worms (\#7) was monitored by means of the phototransducer system while the activity of the other worms was determined by frequent inspection for 10 min periods. On Day 1 (16 March, preceding $2 \mathrm{~d}$ feeding) at 13:00 h (indicated by arrow) the worms were exposed to biofiltered water, and at 11:00 h on Day 3 (indicated by arrow) the biofilter was removed. It was observed that the filtration activity ceased some hours after the introduction of the biofiltered. water, but resumed after about $1 \mathrm{~h}$ when the biofilter was removed. The activity level of all the worms followed this pattern: $56 \pm 7 \%$ (mean of 9 inspection periods of 10 min duration each) of the worms were filter feeding on Day 1 until the biofiltered water was introduced, but almost no filter-feeding activity was observed during Day 2 . After the removal of the biofilter (Day 3) filter-feeding activity increased rapidly over the following hours, with $70 \pm 6 \%$ (mean of 4 inspection periods) of the worms actively filter feeding by the end of Day 3. The chl a level on Day 1 was $2.19 \pm 0.18(n=6) \mu \mathrm{g}$ chl a $1^{-1}$ which fell to 1.5 to $1.9 \mathrm{\mu g} \mathrm{l}^{-1}$ when the biofiltered water was introduced. After removal of the biofilter the algal concentration

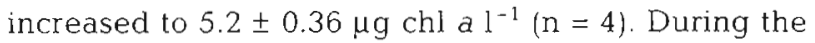
$3 \mathrm{~d}$ the (ambient) water temperature increased from 4.6 to $5.9^{\circ} \mathrm{C}$ which is reflected in the simultaneously increasing stroke frequency. That low water temperatures cause long pumping periods has been shown previously by Riisgărd et al. (1992). In some cases irregular and very high stroke frequencies were measured, however, this phenomenon was attributable to double recording of undulating body movements when the worm positioned itself inappropriately in relation to one of the 2 phototransducers.

Fig. 4 illustrates quite well the basic idea behind the simultaneous field monitoring of filter-feeding activity and concentration of accessible phytoplankton (measured as chl a) performed in the present work. If the phytoplankton concentration falls below a certain level 

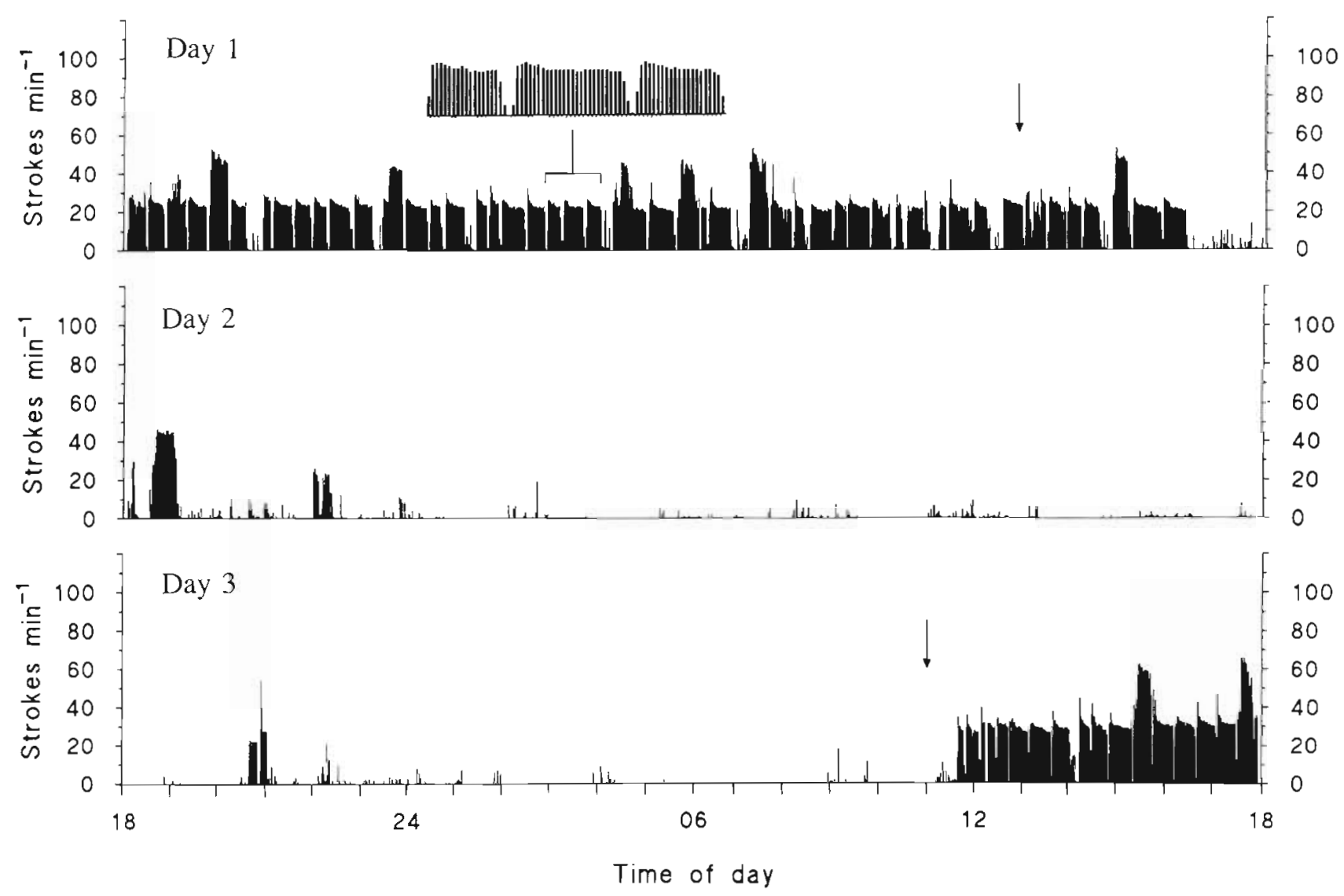

Fig. 4. Nereis diversicolor Laboratory test of phototransducer system demonstrating the effect of adding/removing (arrows) a blofilter to the water running through an aquarium with worms. It is seen that filter-feeding activity ceases when the water is stripped of phytoplankton by the biofilter (mussels); see text. An enlarged picture of 3 feeding-cycles is shown for Day 1

(i.e. 1 to $3 \mu \mathrm{g} \mathrm{chl} \mathrm{al}^{-1}$ ), possibly due to the grazing impact of the Nereis diversicolor population, the worms may stop filter feeding and perhaps begin to feed by surface deposit-feeding or predation. Thus, the phototransducer system may be used in field studies to establish the percentage of the total time used for suspension feeding by $N$. diversicolor under different conditions (e.g. time of year, time of day, water depth, tidal water and degree of eutrophication). In the present work such measurements were performed at different times of the year in 2 areas, Odense Fjord (eutrophic) and Fyns Hoved (unpolluted) (see Fig 2)

\section{RESULTS AND DISCUSSION}

\section{Field investigations}

Odense Fjord

The field measurements carried out in Odense Fjord (Fig. 2) from April to May 1992 (Figs. 5 \& 6) show that filter-feeding activity was sporadic (note the long filtra- tion cycles of 13 to $26 \mathrm{~min}$ at the low temperatures of 6 to $7^{\circ} \mathrm{C}$ ) in April and the first half of May in agreement with low chl a values.

To check the willingness of the worms to undertake filter feeding, a Plexiglas tube (diameter $=20 \mathrm{~cm}$ ) was placed around the worm and algal (Rhodomonas spp.) cells were added (about $50 \mu \mathrm{g} \mathrm{chl} \mathrm{a}$ ] $^{-1}$, periods of algal treatments are indicated on the figures). Soon after the addition, typical bar charts of filter feeding could be observed. When the Plexiglas tube was removed again this resulted in a rapidly vanishing algal concentration and the worms soon stopped filter feeding. In late May the algal concentration had increased (Fig. 6, note the change in scale for chl a) and more steady and pronounced periods of filter-feeding activity, correlated with the fluctuations in the algal biomass, were observed.

\section{Fyns Hoved}

Field measurements were performed on worms in Pughavn at Fyns Hoved (Fig. 2), and representative 

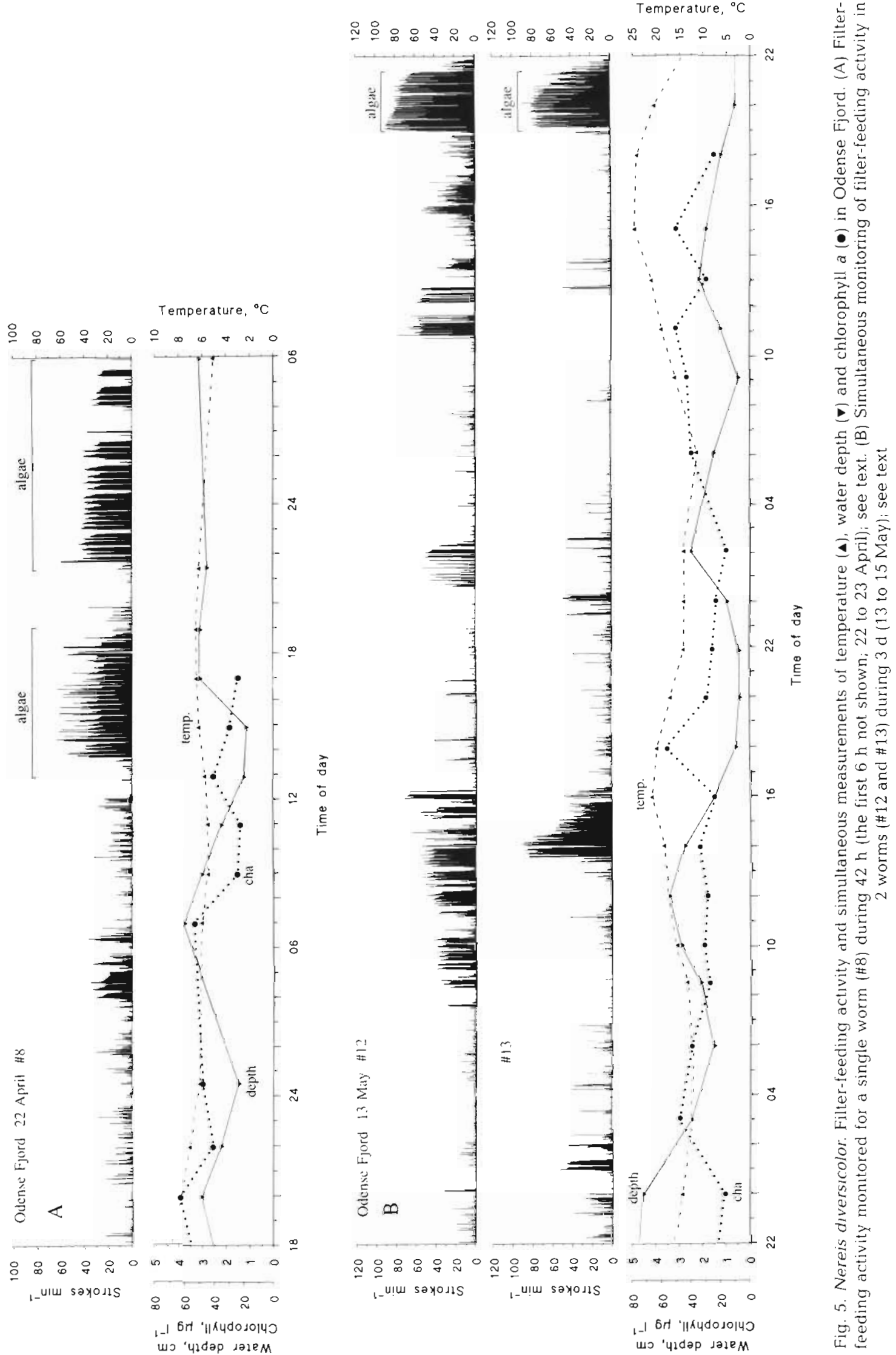


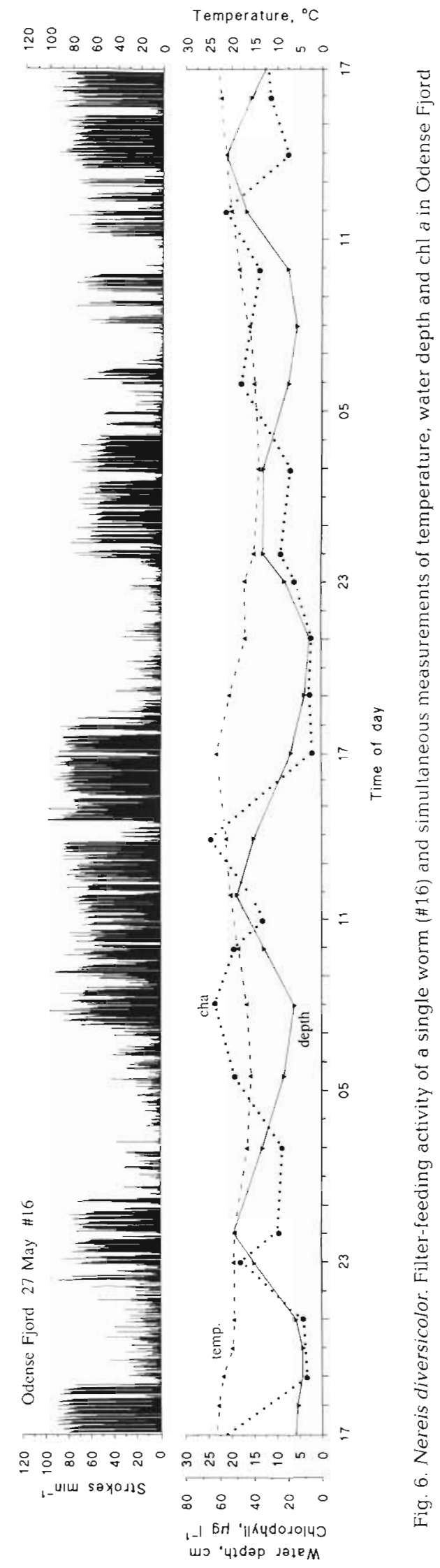

results for August and September 1991 are shown in Fig. 7. In August (Fig. 7A) the chl a concentration was low $\left(2.7 \pm 0.8 \mu \mathrm{g}\right.$ chl a $\left.\mathrm{l}^{-1}\right)$, and only just above the lower limit for stimulating Nereis diversicolor to suspension-feeding behaviour. The worm (\#1) was continuously filter feeding throughout the $32 \mathrm{~h}$ of monitoring. In September, when light was beginning to be a limiting factor for primary production, the chl a concentration fluctuated around the trigger level of 1 to $3 \mu \mathrm{g} \mathrm{chl} \mathrm{a} \mathrm{l}^{-1}$ [continuous filter feeding was observed at 2000 Rhodomonas sp. cells $\mathrm{ml}^{-1}=2.5 \mu \mathrm{g} \mathrm{chl} \mathrm{a}^{-1}$ by Riisgård et al. (1992), but no activity was observed at 1.5 to $1.9 \mu \mathrm{g} \mathrm{chl} \mathrm{al}^{-1}$ in the present work; Fig. 4]. Thus, filter feeding only took place during the afternoon when primary production had elevated the phytoplankton biomass above the trigger level.

\section{Time spent on filter feeding by Nereis diversicolor}

The number of worms, total time of monitoring and percent time Nereis diversicolor spent filter feeding are shown in Table 1. This table also includes mean chl a concentrations and results for 'secondary' tubes (see section 'Field monitoring of filter feeding'). It is seen that filter-feeding activity occurred during 50 to $100 \%$ of the monitoring period during the productive summer period. In early spring and autumn, filter feeding accounted for about 5 to $20 \%$ of the total time. The limitation of the phototransducer system (only 2 worms could be monitored at the same time) has been mentioned previously. To compensate for this restriction, supplementary 'secondary tubes' were used to check for activity during short periods. In particular the poor statistics were compensated for by monitoring a greater number of worms during a long period. The total time of continuous monitoring was $525 \mathrm{~h}$ or about 3 wk, which was complemented with an additional $4.4 \mathrm{wk}$ by means of the 'secondary tubes' (Table 1).

\section{Grazing impact of Nereis diversicolor and effect of a boundary layer on such impact}

In Odense Fjord maximum algal concentrations were observed at high tide (Fig. 6). A possible explanation is that the relatively small volume of water overlying the sediment was almost completely stripped of phytoplankton at low tide (water depth down to $10 \mathrm{~cm}$ ), whereas at high tide, vertical mixing was not sufficient to allow the worms to graze on the whole water column. Collection of water samples for chl a measurements at the surface may explain the high

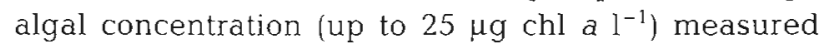
at high tide. Now afterwards, when looking at the 
Temperature, ${ }^{\circ} \mathrm{C}$

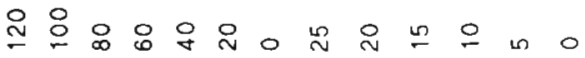
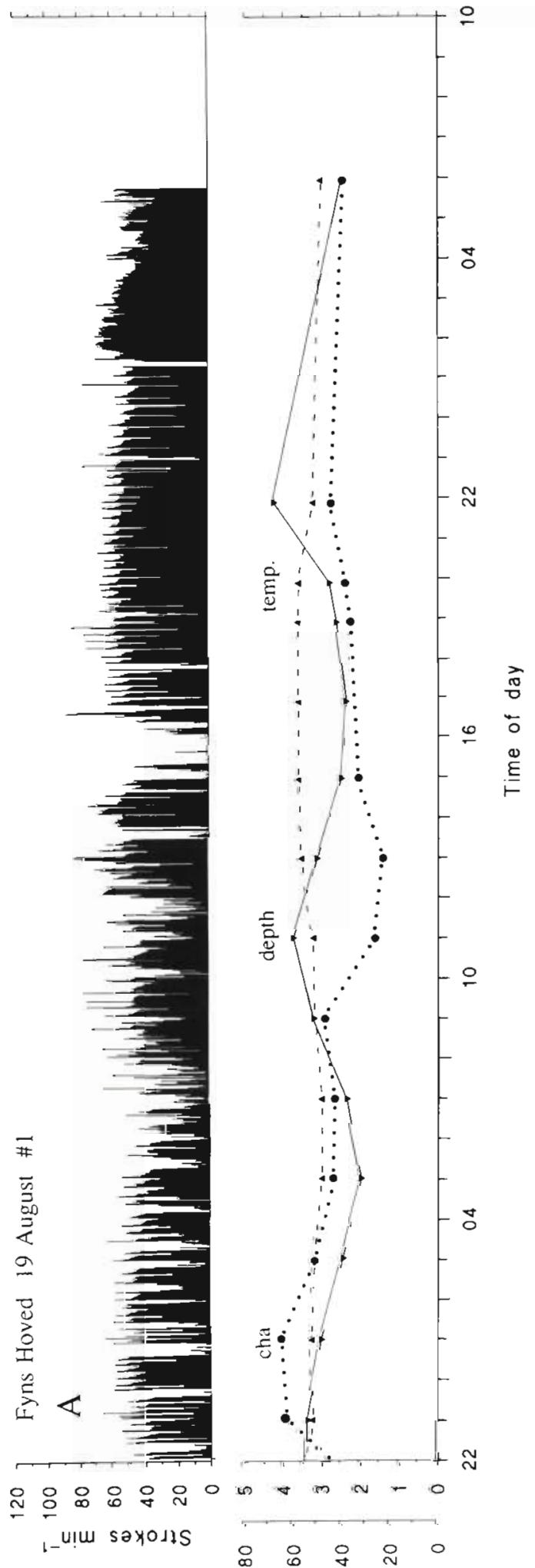

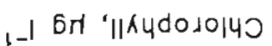

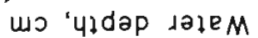

Temperature, ${ }^{\circ} \mathrm{C}$

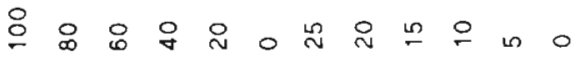

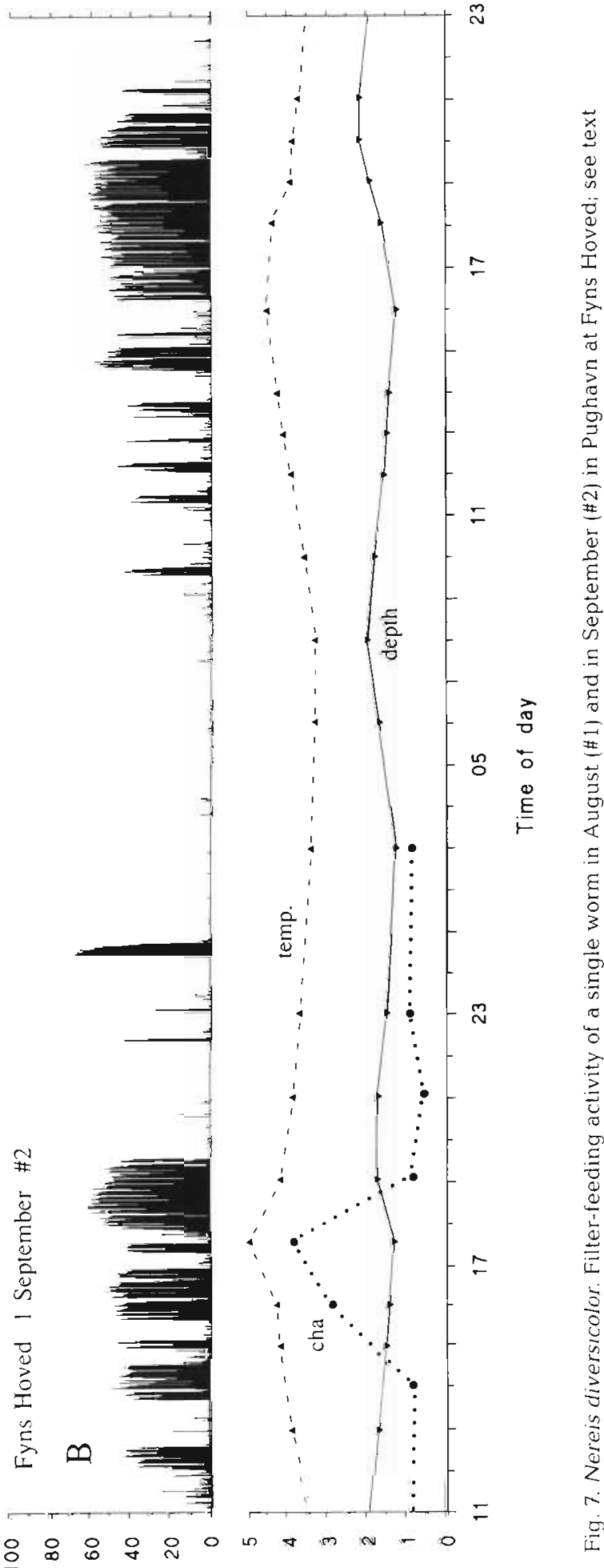

LU!u sayodis

$\infty$ 요 웅

.1 $6 r$ 'Ilxydo 10140 шว 'पдdәр ләлем 
Table 1 Nereis diversicolor. Summary of field data pertaining to locations (OF: Odense Fjord; FH: Fyns Hoved), showing duration of monitoring time with phototransducer system on different worms, total observation time of worms in 'primary' and 'secondary' glass tubes (see text), filtration activity at different times of year and at different phytoplankton concentrations (chl $a_{i}$ no. of measurements shown in brackets)

\begin{tabular}{|c|c|c|c|c|c|c|c|c|c|}
\hline Location & & Date & $\begin{array}{l}\text { Duration } \\
\text { time } \\
\text { (h) }\end{array}$ & $\begin{array}{c}\text { Worm } \\
\text { (\#) }\end{array}$ & $\begin{array}{l}\text { Observation } \\
\text { time } \\
\text { (h) }\end{array}$ & $\begin{array}{l}\text { Chla } \\
\left(\mu \mathrm{gl} \mathrm{l}^{-1}\right)\end{array}$ & $\begin{array}{l}\text { Filtration } \\
\text { activity } \\
(\% \text { time) }\end{array}$ & $\begin{array}{c}\text { Worm } \\
\text { ['secondary' tubes) } \\
\qquad \#)\end{array}$ & $\begin{array}{l}\text { Filtration } \\
\text { activity } \\
(\% \text { time) }\end{array}$ \\
\hline OF & 22 & Apr 1992 & 42 & 8 & 42 & $2.4 \pm 0.9(13)$ & 5.6 & $9,19,11$ & 0 \\
\hline OF & 13 & May 1992 & 48 & 12,13 & 96 & $2.0 \pm 0.7(19)$ & 12.5 & 14,15 & 12.5 \\
\hline OF & 27 & May 1992 & 72 & 16 & 72 & $11.5 \pm 6.4(34)$ & 51.0 & $17,18,19$ & 26.9 \\
\hline OF & 9 & Jul 1992 & 24 & 24,25 & 48 & $15.0 \pm 6.0(13)$ & 54.0 & 26,27 & 25.0 \\
\hline $\mathrm{FH}$ & 15 & Jun 1992 & 59 & 20.21 & 118 & $1.9 \pm 0.9(29)$ & 52.5 & 22,23 & 47.0 \\
\hline $\mathrm{FH}$ & 19 & Aug 1991 & 32 & 1 & 32 & $2.7 \pm 0.8(14)$ & 100.0 & 0 & - \\
\hline $\mathrm{FH}$ & 1 & Sep 1991 & 72 & 2 & 72 & $1.8 \pm 1.2(11)$ & 18.0 & 3,4 & 16.0 \\
\hline $\mathrm{FH}$ & 12 & Sep 1991 & 24 & 5,6 & 45 & $1.8 \pm 0.5(14)$ & 46.7 & 0 & - \\
\hline \multicolumn{5}{|c|}{ Total observation time } & \multicolumn{3}{|l|}{$525 \mathrm{~h}=\mathrm{ca} 3 \mathrm{wk}$} & $748 \mathrm{~h}=\mathrm{ca} 4.5 \mathrm{wk}$ & \\
\hline
\end{tabular}

obtained data, we have become aware of the importance of water samples from near the bottom, because surface values may be much higher than the algal concentration in the near-bottom water actually inhaled by the worms. This suggestion is supported by Fig. 8, which shows that algal biomass decreased with decreasing water depth. The same trend for in- and outgoing tidal water indicates that there was no noticeable import of phytoplankton with the flood or ebb tides. Further, it is clear that the grazing impact of the worms (potentially $5.6 \mathrm{~m}^{3} \mathrm{~m}^{-2} \mathrm{~d}^{-1}$, representing a volume 11 to 55 times greater than the overlying water column; see Table 2) must have been restricted, probably to a thin boundary layer of refiltered water near the bottom. This may explain why even the 'high' sur-

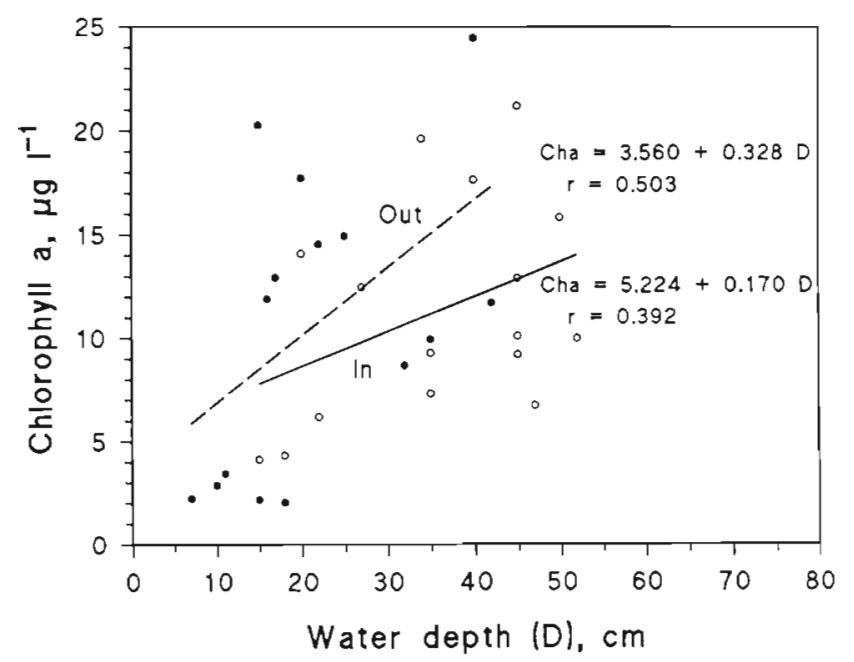

Fig. 8. Chl a in surface-water samples collected in Odense Fjord on 27 May 1992 as a function of water depth, with regression lines and regression equations. : outgoing (ebb) tide water; o: incoming (flood) tide water face values of 11.5 and $15 \mu \mathrm{g} \mathrm{chl} \mathrm{a}^{-1}$ in Odense Fjord in May and July resulted in filtration activity for only about $50 \%$ of the total monitoring time (Table 1).

An additional indication for the existence of a phytoplankton-depleted boundary layer was the high growth rates $\left(3.9 \%\right.$ of body wet wt $\mathrm{d}^{-1}$ ) recorded in Nereis diversicolor in glass tubes elevated $15 \mathrm{~cm}$ above the bottom (and thus the boundary layer) in the same area (Vedel \& Riisgard 1993). Table 2 shows that the total biomass of the $N$. diversicolor population at the station in Odense Fjord was slowly decreasing from March to June, and that the disappearance of the biggest worms (after spawning during the spring) was not completely counterbalanced by growth of the smaller size classes. No net increase in population biomass and high population filtration potentials, increasing from $3.6 \mathrm{~m}^{3} \mathrm{~m}^{-2} \mathrm{~d}^{-1}$ from March $\left(5.2^{\circ} \mathrm{C}\right)$ to $7.0 \mathrm{~m}^{3}$ $\mathrm{m}^{-2} \mathrm{~d}^{-1}$ in June $\left(19.2^{\circ} \mathrm{C}\right)$ also indicates meagre food conditions in the near-bottom water. In future, water samples should be collected at different distances (cm scale) from the bottom to reveal the thickness of the phytoplankton-depleted boundary layer. Measurements of algal biomass in the near-bottom water may give a correlation between filter-feeding activity and chl a similar to that found in the laboratory experiments (Fig. 4). All measurements in the present work were performed in calm weather. The breakdown of the boundary layer in windy weather presumably results in higher filter-feeding activity than that shown in Table 1.

\section{Observations}

Numerous observations of Nereis diversicolor were made during the course of the field measurements. In Odense Fjord $N$. diversicolor often emerged from the 
Table 2. Nereis diversicolor. Size distribution, population density and biomass and estimated population pumping rate of worms at the Odense Fjord station (Fig. 1) from March to June 1992. Individual clearance (at $17^{\circ} \mathrm{C}$ ) and dependence of clearance on temperature are adapted from Riisgârd et al. 1992

\begin{tabular}{|c|c|c|c|c|c|}
\hline \multirow{2}{*}{$\begin{array}{l}\text { Size } \\
\text { (wet wt, mg) }\end{array}$} & \multirow{2}{*}{$\begin{array}{l}\text { Individual } \\
\text { clearance } \\
\left(17^{\circ} \mathrm{C}\right) \\
\left(\mu 1 \mathrm{~s}^{-1}\right)\end{array}$} & \multicolumn{4}{|c|}{$\begin{array}{l}\text { Density } \\
\text { (ind. } \mathrm{m}^{-2} \text { ) }\end{array}$} \\
\hline & & Mar & Apr & May & Jun \\
\hline$<50$ & 7 & 1713 & 1771 & 1748 & 1706 \\
\hline $50-100$ & 17 & 373 & 408 & 448 & 406 \\
\hline $100-150$ & 37 & 163 & 138 & 224 & 265 \\
\hline $150-200$ & 57 & 245 & 221 & 238 & 153 \\
\hline $200-250$ & 77 & 93 & 163 & 182 & 125 \\
\hline $250-300$ & 97 & 70 & 128 & 70 & 154 \\
\hline $300-350$ & 117 & 82 & 35 & 70 & 112 \\
\hline $350-400$ & 137 & 82 & 70 & 42 & 28 \\
\hline $400-450$ & 157 & 47 & 58 & 28 & 28 \\
\hline $450-500$ & 177 & 30 & 58 & 28 & 14 \\
\hline $500-550$ & 197 & 12 & 12 & 28 & \\
\hline $550-600$ & 217 & 35 & 35 & 14 & \\
\hline $600-650$ & 237 & 12 & 12 & & \\
\hline $650-700$ & 257 & 23 & & & \\
\hline $700-750$ & 277 & 12 & & & \\
\hline \multicolumn{2}{|c|}{ Population density (ind. $\mathrm{m}^{-2}$ ) } & 3032 & 3109 & 3120 & 2991 \\
\hline \multicolumn{2}{|c|}{ Biomass $\left(\mathrm{g} \mathrm{m}^{-2}\right)$} & 343 & 326 & 294 & 268 \\
\hline \multicolumn{2}{|c|}{ Filtration capacity $\left(\mathrm{m}^{3} \mathrm{~m}^{-2} \mathrm{~d}^{-1}\right)$} & $\begin{array}{c}\text { at } 5.2^{\circ} \mathrm{C} \text { : } \\
\quad 3.6\end{array}$ & $\begin{array}{l}7.5^{\circ} \mathrm{C}: \\
4.2\end{array}$ & $\begin{array}{c}13.2^{\circ} \mathrm{C}: \\
5.6\end{array}$ & $\begin{array}{c}19.2^{\circ} \mathrm{C} \\
7.0\end{array}$ \\
\hline
\end{tabular}

feeding activity was never observed at Fyns Hoved, possibly due to a great number of fish fry (mainly flounder) and gobies Pomatoschistus minutus (20 to 40 ind. $\mathrm{m}^{-2}$ ), always inspecting the bottom for food. If a worm was placed on the sediment surface at this location it was immediately attacked by the fish before being able to burrow into the sediment.

Nereis diversicolor may adopt a number of feeding methods depending on time of year, primary productivity and other local conditions. To elucidate further the feeding biology of $N$. diversicolor, the present method of monitoring filter feeding may be supplemented by simultaneous underwater video-recording of the sediment surface to reveal the worms' activities when not filter feeding. Such studies combined with a more appropriate water-sampling technique for chl a measurements will be undertaken as part of further studies of the feeding behaviour of $N$. diversicolor tube to surface deposit-feed on benthic diatoms just after low slack water. In some cases the worms were observed feeding on sea-lettuce Ulva lactuca, and additionally pieces of $U$. lactuca were seen to be drawn down into the tubes of the buried worms. Such surface-

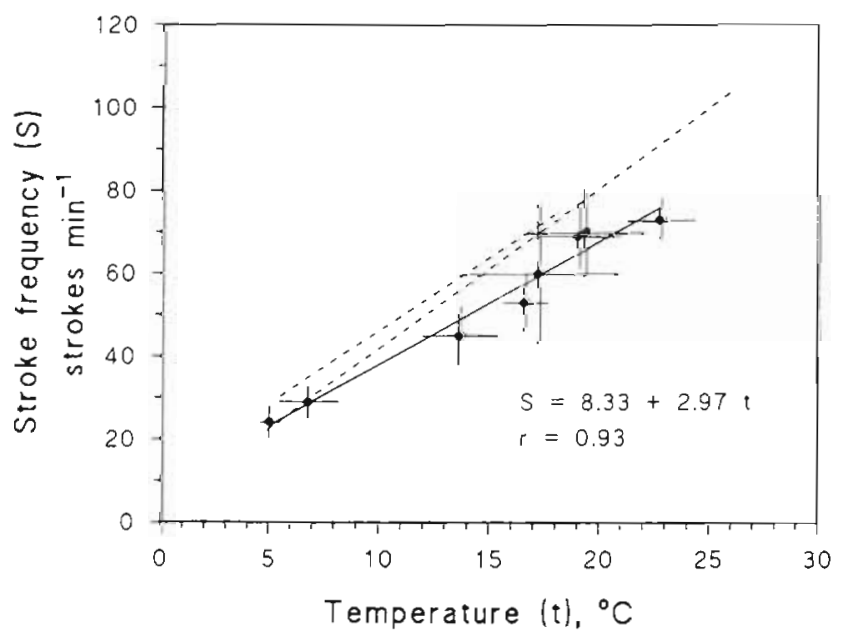

Fig. 9. Nereis diversicolor. Recorded stroke frequency ( $\pm \mathrm{SD}$ ) in the field as a function of temperature. Regression line and its equation is shown. Dotted lines refer to laboratory experiments made by Riisgård et al. (1991 b; \#9 and \#8 in Fig. 3)

\section{Effect of temperature on stroke frequency}

All measured stroke frequencies of filter feeding Nereis diversicolor obtained in the field are shown as a function of water temperature in Fig. 9. The figure also shows the regression lines found in 2 previous laboratory experiments in which the acute effect of temperature on stroke frequency (and thus filtration rate) was recorded (Riisgård et al. 1992). The increase in stroke activity with temperature led to a doubling of the population filtration potential from March to June in Odense Fjord although the population biomass was reduced by about $30 \%$ in the same period (Table 2). The effect of temperature in the 'natural-temperature adapted' worms and the acute temperature effect on unadapted worms are pretty much the same, indicating absence of temperature adaptation of filtration rate in $N$. diversicolor. A similar absence of temperature adaptation has previously been found for Mytilus edulis (Jørgensen et al. 1990, Riisgård 1991a).

Acknowledgements. Thanks are due to Dr D. Hunter and Prof. C. Barker Jorgensen for critically reading the manuscript. 


\section{LITERATURE CITED}

Arvola, L. (1981). Spectrophotometric determination of chlorophyll $a$ and phaeopigments in ethanol extraction. Ann. bot. finn. 18: 211-227

Depledge. M. H., Andersen, B. B. (1990). A computer-aided physiological monitoring system for continous, long-term recording of cardiac activity in selected invertebrates. Comp. Biochem. Physiol. 96A(4): 473-477

Jorgensen, C. B., Larsen, P. S., Riisgård, H. U. (1990). Effects of temperature on the mussel pump. Mar. Ecol. Prog. Ser 64: $89-97$

This article was submitted to the editor
Riisgård, H. U. (1991a). Filtration rate and growth in the blue mussel, Mytilus edulis Linnaeus, 1758: dependence on algal concentration. J. Shellfish Res. 10: 29-35

Riisgărd, H. U. (1991b). Suspension feeding in the polychaete Nereis diversicolor. Mar. Ecol. Prog. Ser 70: 29-37

Riisgård, H. U., Vedel, A., Boye, H., Larsen, P. S. (1992). Filternet structure and pumping activity in the polychaete Nereis diversicolor: effects of temperature and pumpmodellıng. Mar. Ecol. Prog. Ser. 83: 79-89

Vedel, A., Riisgard, H. U. (1993). Filter-feeding in the polychaete Nereis diversicolor: growth and bioenergetics. Mar. Ecol. Prog. Ser. 100: 145-152

Manuscript first received: April 7, 1993

Revised version accepted: June 14, 1993 